J. Akademika Kim. 6(2): 125-131, May 2017

ISSN 2302-6030 (p), 2477-5185 (e)

\title{
UJI AKTIVITAS ANTIOKSIDAN EKSTRAK AIR DAN EKSTRAK ETANOL DAUN KELOR (Moringa Oleifera LAM)
}

\author{
Antioxidant Activity Tests of Water and Ethanol Extracts of Moringa (Moringa \\ oleifera LAM) Leaves
}

\author{
*Rizkayanti, Anang Wahid. M. Diah, dan Minarni Rama Jura
}

Pendidikan Kimia/FKIP - Universitas Tadulako, Palu - Indonesia 94118

Recieved 14 March 2017, Revised 17 April 2017, Accepted 15 May 2017

\begin{abstract}
Moringa (Moringa oleifera Lam) leaves contains many molecules as inhibitors for free radicals such as phenolic compounds (phenolic acids, flavonoids, quinones, coumarins, lignans, stilbenes, tannins), nitrogen compounds (alkaloids, amines, betalain), vitamins, terpenoids (including carotenoids), and several other endogenous metabolites as antioxidants. This study aimed to determine the antioxidant potency of water and ethanol extracts of moringa (moringa oleifera Lam) leaves obtained by maceration and dekok. The concentration of free radical 1,1-diphenyl-2-picrylhydrazyl (DPPH) was analyzed using $U V$-Vis spectrophotometer after addition of various concentrations of Moringa leaves extracts. Various concentrations of moringa leaves extracts used were $20 \mathrm{ppm}, 40 \mathrm{ppm}, 60 \mathrm{ppm}$ and $80 \mathrm{ppm}$. Vitamin C solutions as the positive control were prepared on similar various concentrations. The negative control was prepared using DPPH solutions dissolved in absolute ethanol. The results indicated that the ethanol extract of moringa leaves prepared by maceration method showed the antioxidant potency with $I C_{50}$ value of 22,1818 ppm, but the $I C_{50}$ value of water extract of moringa leaves prepared by dekok was $57,5439 \mathrm{ppm}$. While, the $I C_{50}$ value of Vitamin $C$ was $8,8084 \mathrm{ppm}$. Based on the IC $C_{50}$ data it can be concluded that Vitamin $C$ is stronger antioxidant than moringa leaves extracts.
\end{abstract}

Keywords: antioxidants, moringa leaves, DPPH, free radicals.

\section{Pendahuluan}

Indonesia memiliki sumber daya alam yang sangat beranekaragam dan sangat melimpah. Sumber daya alam ini dikelola untuk kesejahteraan manusia dan berperan penting dalam mendukung perekonomian negara. Salah satu pemanfaatan sumber daya alam tumbuhan oleh manusia adalah sebagai sumber makanan, yaitu sebagai sumber karbohidrat, protein, lemak, vitamin dan mineral serta nutrisi.Usaha pengolahan bahan pangan dapat dilakukan dengan mencari bahan pangan baru atau mengolah bahan pangan yang sudah ada menjadi produk olahan yang beragam dengan harga yang bisa dijangkau oleh masyarakat kurang mampu (Palupi, dkk., 2007). Selain sebagai bahan sumber makanan, sumber daya alam tumbuhan juga sering dimanfaatkan sebagai bahan obat alami.

\footnotetext{
*Correspondence:

Rizkayanti

Program Studi Pendidikan Kimia, Fakultas Keguruan dan Ilmu Pendidikan, Universitas Tadulako email: rizkayanti@rocketmail.com

Published by Universitas Tadulako 2017
}

Seiring dengan meningkatnya minat masyarakat terhadap obat bahan alami, berbagai obat dari ekstrak tumbuhan mulai menjadi perhatian.Penggunaan obat tradisional dengan memanfaatkan tanaman yang berkhasiat obat semakin meningkat dan dianggap sebagai salah satu jawaban untuk mengatasi masalah masyarakat dalam hal pemenuhan kebutuhan kesehatan, karena obat tradisional lebih murah, mudah diperoleh dan efek samping relatif kecil. Kelebihan dari pengobatan dengan menggunakan ramuan tanaman tidak menimbulkan efek samping seperti yang sering terjadi pada pengobatan secara sintesis (Mangan, 2003).

Tubuh membutuhkan antioksidan untuk menetralisis radikal bebas yang dapat membantu melindungi tubuh dari serangan radikal bebas dan meredam dampak negatifnya. Antioksidan merupakan suatu senyawa yang sangat berguna bagi kesehatan manusia. Senyawa antioksidan dapat menginaktifasi berkembangnya reaksi oksidasi sehingga sering 
digunakan sebagai radikal bebas. Radikal bebas merupakan salah satu bentuk senyawa reaktif, yang secara umum diketahui sebagai senyawa yang memiliki elektron yang tidak berpasangan di kulit terluarnya (Winarsi, 2007). Radikal bebas terbentuk pada saat molekul yang kehilangan elektron menjadi tidak stabil. Radikal bebas juga merupakan produk alamiah hasil metabolisme sel.

Tubuh memiliki sistem pertahanan alami untuk menetralisir radikal bebas agar tidak berkembang dan menjadi berbahaya bagi tubuh. Pengaruh lingkungan dan kebiasaan buruk seperti radiasi ultraviolet, polusi, kebiasaan mengonsumsi "junk food" dan merokok, dapat membuat sistem pertahanan tubuh tidak mampu menghadapi radikal bebas yang berjumlah besar. Adanya radikal bebas didalam tubuh manusia berperan dalam patologi dari berbagai penyakit degeneratif yakni kanker, aterosklerosis, rematik, jantung koroner, katarak, dan penyakit degenerasi saraf seperti perkinson (Silalahi, 2006). Radikal bebas dapat ditangkal atau diredam dengan pemberian antioksidan atau dengan mengkonsumsi antioksidan (Halliwel, 2007). Efek radikal bebas dapat menyebabkan peradangan dan penuaan serta memacu zat karsinogenik yang menyebabkan kanker.Tubuh membutuhkan antioksidan untuk menetralisir radikal bebas yang dapat membantu melindungi dari serangan radikal bebas dan meredam dampak negatifnya. Antioksidan merupakan suatu senyawa yang sangat berguna bagi kesehatan manusia. Senyawa antioksidan dapat menginaktifasi berkembangnya reaksi oksidasi sehingga sering digunakan sebagai radikal bebas (Winarsi, 2007).

Banyak bahan pangan yang dapat menjadi sumber antioksidan alami, misalnya rempahrempah, teh, coklat, biji-biji serelia, sayursayuran, enzim dan protein. Kebanyakan sumber antioksidan alami ialah tumbuhan dan umumnya merupakan senyawa fenolik yang tersebar di seluruh bagian tumbuhan (Sarastani, dkk., 2002). Senyawa fenolik atau polifenolik antara lain dapat berupa golongan flavonoid. Kemampuan flavonoid sebagai antioksidan telah banyak diteliti belakangan tahun ini, dimana flavonoid memiliki kemampuan untuk merubah atau mereduksi radikal bebas dan juga sebagai anti radikal bebas (Pietta, 2000).

Salah satu tumbuhan yang berpotensi sebagai tumbuhan obat ialah kelor. Tanaman kelor (Moringa oleifera Lam) telah dikenal selama berabad-abad sebagai tanaman multiguna padat nutrisi dan berkhasiat obat. Kelor dikenal sebagai the miracle tree atau pohon ajaib karena terbukti secara alamiah merupakan sumber gizi berkhasiat obat yang kandungannya di luar kebiasaan kandungan tanaman pada umumnya (Karyadi, 2004).

Kelor diketahui mengandung lebih dari 90 jenis nutrisi berupa vitamin esensial, mineral, asam amino, antipenuaan, dan antiinflamasi. Kelor mangandung 539 senyawa yang dikenal dalam pengobatan tradisional afrika dan india serta telah digunakan dalam pengobatan tradisional untuk mencagah lebih dari 300 penyakit, berbagai bagian dari tanaman kelor bertindak sebagai stimulan jantung dan peredaran darah, memiliki antitumor, antipiretik, antiepilepsi, antiinflamasi, antiulcer, diuretik, antihipertensi, menurunkan kolesterol, antioksidan, antidiabetik, antibakteri dan antijamur (Shintia, 2014).

Tanaman kelor banyak mengandung berbagai molekul penghambat radikal bebas, seperti senyawa fenolik (asam fenolik, flavonoid, kuinon, kumarin, lignan, stilbenes, tanin), senyawa nitrogen (alkaloid, amina, betalain), vitamin, terpenoid (termasuk karotenoid), dan beberapa metabolit endogen lainnya yang kaya akan aktivitas antioksidan(Karyadi, 2004). Senyawa metabolit ini umumnya bersifat polar sehingga dalam penelitian ini digunakan pelarut polar yaitu etanol dan air.Pelarut polar ini diharapkan dapat mencari lebih banyak senyawa yang berpotensi sebagai antioksidan tersebut.

Tanaman kelor, menurut sejarahnya berasal dari kawasan sekitar Himalaya dan India, kemudianmenyebar ke kawasan disekitarnya hinggake benua Afrika dan Asia Barat. Di beberapa negara dibenua Afrika seperti Ethiopia, Sudan, Madagaskar, Somalia, Kenya dijadikan negara dengan programpemulihan tanah yang kering dan gersang dengan ditanamikelor karena tanaman kelor mudah tumbuh pada tanah kering dan gersang. Tanaman kelor di Indonesia mempunyai nama lokal yaitu kelor (Jawa, Sunda, Bali,Lampung), Kerol (Buru), Marangghi (Madura), Moltong (Flores), Kelo (Gorontalo), Keloro (Bugis), Kawano (Sumba), Ongge (Bima), Hau fo (Timor) (Aliya, 2006).

Sejak zaman dahulu daun kelor telah diketahui memiliki berbagai manfaat khususnya untuk kesehatan.Para orang tua jaman dulu telah memanfaatkan daun kelor ini untuk penyembuhan beberapa jenis penyakit. Penyakit yang paling sering umum diobati dengan penggunaan daun kelor ini adalah penyakit demam.Selain itu, daun kelor juga biasa digunakan untuk bahan sayuran. Beberapa 
penjelasan bahwa daun kelor memiliki manfaat sebagai antimikroba, antibakteri, antioksidan, mempercepat penyembuhan berbagai penyakit radang, mengobati penyakit flu dan pilek, cacingan, bronchitis, kanker, dan tiroid (Aliya, 2006).

Tulisan ini bertujuan untuk memberikan informasi kepada masyarakat di Sulawesi Tengah pada umumnya dan Kota Palu khususnya, terkait dengan daun kelor yang dapat menghambat aktivitas radikal bebas dan kemampuannya sebagai bahan antioksidan alami.

\section{Metode \\ Alat dan Baban}

Peralatan yang digunakan adalah neraca analitik(Merck-210g), corong, blender, gemmy orbit shaker $(V R N-480)$,seperangkat alat rotary vacum evaporator(EYELA CCA-1111), spektrofotometer UV-Vis $\left(T 80_{+}\right)$, labu takar, pipet volum, aqua bath, kuvet, dan peralatan gelas yang umum di laboratorium. Sedangkan bahan-bahan yang digunakan: daun kelor, etanol absolut (Merck), air, aquades, 1,1-difenil2-pikrilhidrazil DPPH(Merck) dan Vitamin $\mathrm{C}($ Merck $)$.

\section{Cara Kerja}

\section{Preparasi Sampel}

Langkah dalam preparasi sampel pada daun kelor yaitu daun kelor yang segar dan dibersihkan selanjutnyadikeringkan dengan cara diangin-anginkankan selama 14 hari (2 minggu). Setelah kering, kemudian sampel daun kelor tersebut dihaluskan menggunakan blender. Setelah itu,daun kelor yang halus siap untuk diekstraksi. Serbuk kering daun kelor (Moringa Oleifera Lam) diekstraksi menggunakan dua metode yang berbeda yaitu sebagai berikut:

\section{Ekstraksi daun kelor dengan menggunakan metode maserasi}

Ekstrak daun kelor (Moringa Oleifera Lam) dibuat dengan mengekstraksi 30 gram serbuk daun kelor secara maserasi dengan pelarut etanol hingga terekstraksi sempurna. Simplisia direndam dalam pelarut etanol absolut sebanyak $300 \mathrm{~mL}$ selama 2 × 24 jam. Setelah itu filtrat yang diperoleh disaring dan residunya dimaserasi kembali dengan pelarut etanol. Selanjutnyahasil ekstraksi dipekatkan menggunakan rotary vacum evaporator.
Ekstraksi daun kelor dengan menggunakan metode dekok

30 gramserbukkeringdaunkelordimasukkan ke dalam gelas kimia dan ditambahkan aquades hingga $300 \mathrm{~mL}$.Selanjutnya dipanaskan dalam aqua bath selama 30 menit. Waktu 30 menit dihitung setelah suhu dalam gelas kimia telah mencapai $90^{\circ} \mathrm{C}$.

\section{Pengujian Aktivitas Antioksidan secara} Kuantitatif dengan Metode DPPH

19,7 mg DPPH dilarutkan dengan etanol absolut dalam labu ukur $100 \mathrm{~mL}$, kemudian dicukupkan volumenya dengan etanol absolut sampai garis tanda, kemudian dimasukkan dalam botol gelap.

\section{Pembuatan Larutan Blanko}

Larutan DPPH 0,5 mM dipipet sebanyak 5 mL, kemudian dimasukkan kedalam labu ukur $25 \mathrm{~mL}$, dicukupkan dengan etanol/air sampai garis tanda.

Pembuatan Larutan uji ekstrak air dan ekstrak etanol daun kelor (Moringa Oleifera Lam)

Masing-masing sebanyak $25 \mathrm{mg}$ ekstrak daun kelor, dimasukkan ke dalam dua buah labu ukur $25 \mathrm{~mL}$. Labu pertama kemudian dicukupkan volumenya dengan etanol absolut sampai tanda batas, kemudian labu kedua dicukupkan volumenya dengan air sampai tanda batas. Selanjutnya dari masing-masing larutan induk tersebut dibuat seri konsentrasi 20 ppm, 40 ppm, 60 ppm dan 80 ppm.

Pengukuran serapan dengan menggunakan spektrofotometer UV-VIS

Masing-masing larutan uji di pipet sebanyak 0,5 mL, $1 \mathrm{~mL}, 1,5 \mathrm{~mL}$, dan $2 \mathrm{~mL}$, dimasukkan kedalam labu ukur $25 \mathrm{~mL}$, kemudian ditambahkan $5 \mathrm{~mL}$ larutan DPPH selanjutnya volumenya dicukupkan dengan etanol absolut/air sampai garis tanda. Larutan tersebut kemudian dihomogenkan dan didiamkan selama 20 menit, selanjutnya diukur absorbansinya dengan spektrofotometer UVVIS pada panjang gelombang $517 \mathrm{~nm}$.Semua pengerjaan dilakukan dalam ruangan yang terhindar dari cahaya matahari.

\section{Pembuatan larutan pembanding vitamin $C$}

$25 \mathrm{mg}$ vitamin $\mathrm{C}$ ditambahkan aquades secukupnya, kemudian volume akhir dicukupkan dengan etanol absolut hingga 25 mL. Kemudian dari larutan tersebut dibuat seri 
konsentrasi 20 ppm, 40 ppm, 60 ppm, dan 80 ppm. Pengukuran serapan dengan menggunakan
spektrofotometer UV-Vis

Masing-masing larutan uji dipipet sebanyak 0,5 mL, $1 \mathrm{~mL}, 1,5 \mathrm{~mL}$, dan $2 \mathrm{~mL}$, kemudian dimasukkan kedalam labu ukur $25 \mathrm{~mL}$, kemudian ditambahkan $5 \mathrm{~mL}$ larutan DPPH lalu volumenya dicukupkan dengan etanol absolut sampai garis tanda. Larutan tersebut kemudian dihomogenkan dan didiamkan selama 20 menit, selanjutnya diukur absorbansinya dengan spektrofotometri UVVIS pada panjang gelombang $517 \mathrm{~nm}$.Semua pengerjaan dilakukan dalam ruangan yang terhindar dari cahaya matahari.

\section{Pengukuran Daya Antioksidan Ekstrak Daun} Kelor dan Larutan Pembanding Vitamin $C$

Serapan diukur setelah didiamkan selama 20 menit pada panjang gelombang $517 \mathrm{~nm}$. Hasil penetapan antioksidan dibandingkan dengan vitamin C (Zuhra, dkk., 2008)'

\section{Hasil dan Pembahasan}

Pengujian aktivitas antioksidan pada ekstrak daun kelor dengan metode pengujian menggunakan 1,1-difenil-2pikrilhidrazil (DPPH). Metode uji antioksidan menggunakan DPPH adalah salah satu metode uji kuantitatif untuk menentukan daya aktivitas daun kelor sebagai antioksidan. Metode DPPH ini dipilih karena merupakan metode yang sederhana, mudah, cepat dan peka serta hanya memerlukan sedikit sampel untuk evaluasi aktivitas antioksidan dari senyawa bahan alam (Molyneux, 2004).

Prinsip pengukuran aktivitas antioksidan secara kuantitatif menggunakan metode DPPH ini adalah adanya perubahan intensitas warna ungu DPPH yang sebanding dengan konsentrasi larutan DPPH tersebut. Radikal bebas DPPH yang memiliki elektron tidak berpasangan akan memberikan warna ungu. Warna akan berubah menjadi kuning saat elektronnya berpasangan. Perubahan intensitas warna ungu ini terjadi karena adanya peredaman radikal bebas yang dihasilkan oleh bereaksinya molekul DPPH dengan atom hidrogen yang dilepaskan oleh molekul senyawa sampel sehingga terbentuk senyawa difenil pikril hidrazin dan menyebabkan terjadinya peluruhan warna DPPH dari ungu ke kuning.

Perubahan warna ini akan memberikan perubahan absorbansi pada panjang gelombang maksimum DPPH menggunakan spektrofotometer UV-Vis sehingga akan diketahui nilai aktivitas peredaman radikal bebas yang dinyatakan dengan nilai $\mathrm{IC}_{50}$ (Inhibitory concentration). Nilai $\mathrm{IC}_{50}$ didefinisikan sebagai besarnya konsentrasi senyawa uji yang dapat meredam radikal bebas sebanyak 50\%(Molyneux, 2004). Semakin kecil nilai $\mathrm{IC}_{50}$ maka aktivitas peredaman radikal bebas semakin tinggi.

Pengukuran aktivitas antioksidan secara spektrofotometer dilakukan pada panjang gelombang $517 \mathrm{~nm}$, yang merupakan panjang gelombang maksimum DPPH.Panjang gelombang maksimum ini memberikan serapan paling maksimal dari larutan uji dan memberikan kepekaan paling besar.

Menurut Ozcelik, dkk. (2003), senyawa DPPH sensitif terhadap beberapa basa Lewis dan jenis pelarut, serta oksigen. Metode $\mathrm{DPPH}$ didasarkan pada penurunan nilai absorbansi akibat perubahan warna larutan. Larutan yang mula-mula berwarna ungu akan berubah menjadi warna kuning. Perubahan ini terjadi saat radikal DPPH ditangkap oleh antioksidan yang melepas atom hidrogen untuk menangkap DPPH-H stabil.Reaksi antara antioksidan dengan molekul DPPH dapat dilihat pada Gambar 1

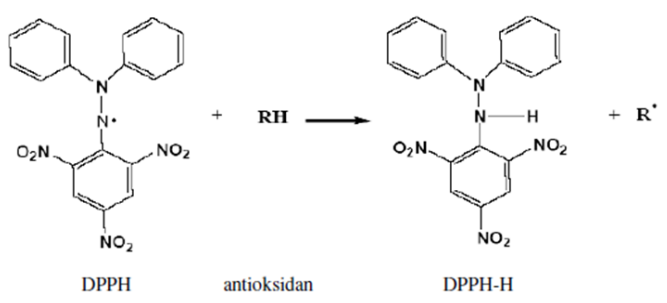

Gambar 1.Reaksi Antara Antioksidan dan Molekul DPPH (Prakash, 2011)

Hasil pengamatan pada proses pengukuran serapan ekstrak daun kelor dan vitamin C disajikan dalam Gambar 2. Berdasarkan data pada gambar tersebut, dapat dilihat bahwa nilai absorbansi DPPH semakin berkurang seiring dengan bertambahnya konsentrasi ekstrak daun kelor. Hal ini dapat terjadi oleh karena adanya reduksi radikal DPPH oleh antioksidan, dimana semakin tinggi konsentrasi ekstrak daun kelor maka partikel-partikel senyawa antioksidan yang terkandung akan semakin banyak sehingga semakin besar pula aktivitas antioksidannya dan menyebabkan absorbansi DPPH semakin berkurang (Talapessy, dkk., 2013). Hal yang sama juga terlihat pada pembanding vitamin 
C dengan variasi konsentrasi yang sama dengan ekstrak daun kelor, dimana seiring dengan bertambahnya konsentrasi vitamin C, maka absorbansi DPPH semakin berkurang.

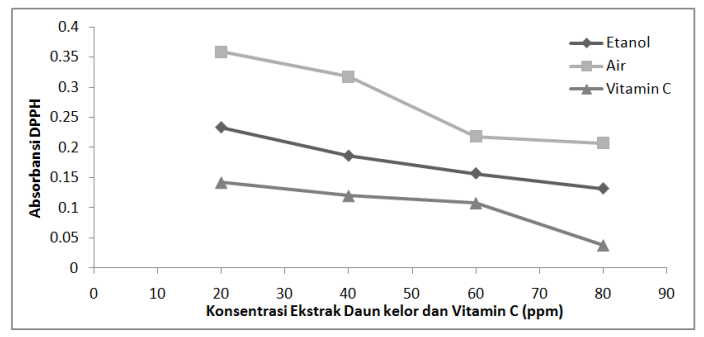

Gambar 2. Grafik Hubungan Absorbansi Dengan Konsentrasi Ekstrak Daun Kelor

Berdasarkan hasil pengukuran absorbansi tersebut, dapat ditentukan pula persentase penghambatan radikal bebas oleh ekstrak daun kelor dan vitamin $\mathrm{C}$ tersebut pada berbagai konsentrasi yang disajikan pada Gambar 3. Data tersebut menunjukkan bahwa ekstrak etanol dengan menggunakan metode maserasi memiliki aktivitas antioksidan yang sangat kuat, sedangkan ekstrak air dengan metode dekok memiliki aktivitas antioksidan yang lemah.Vitamin C sebagai kontrol positif juga memiliki aktivitas antioksidan yang sangat kuat. Besarnya antioksidan ekstrak etanol berbeda dengan besarnya aktivitas antioksidan vitamin C. Perbedaan ini diartikan bahwa ekstrak etanol memiliki aktivitas antioksidan lebih lemah dibandingkan vitamin C. Vitamin $\mathrm{C}$ merupakan antikosidan yang bekerja sebagai oxygen scavengers, yaitu mengikat oksigen sehingga tidak mendukung reaksi oksidasi. Dalam hal ini, vitamin $\mathrm{C}$ akan mengadakan reaksi dengan oksigen yang berada dalam sistem sehingga jumlah oksigen akan berkurang. Selain vitamin C, senyawa yang bekerja sebagai oxygen scavengers diantaranya askorbil palminat, asam eritorbat, dan sulfit (Gordon, 1990). Peningkatan konsentrasi senyawa mempengaruhi aktivitas antioksidannya. Perbandingan tersebut dapat dilihat sebagai persen penghambatan radikal bebas DPPH dari ekstrak etanol, ekstrak air, dan kontrol positif vitamin C dapat dilihat pada Gambar 3.

\section{Pengukuran $I C_{50}$ Ekstrak Daun Kelor}

Uji antioksidan dalam penelitian ini menggunakan parameter $\mathrm{IC}_{50}$ (Inhibition concentration) untuk menginterpretasikan hasil pengujian dengan metode uji menggunakan DPPH. Nilai $\mathrm{IC}_{50}$ diperoleh dari beberapa

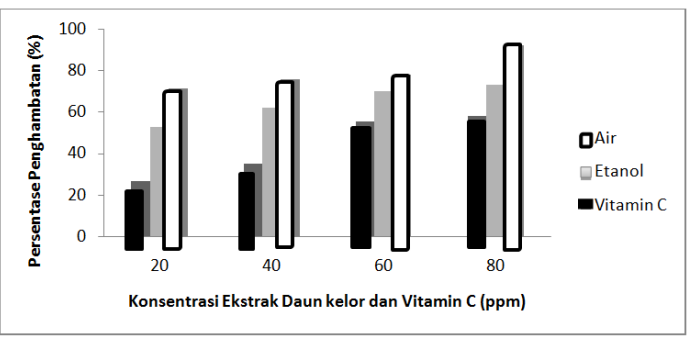

Gambar 3. Perbandingan Persentase Penghambatan Ekstrak Daun Kelor dengan Vitamin C.

tahapan yaitu menghitung nilai log konsentrasi dan nilai probit untuk masing-masing persentase aktivitas penghambat radikal bebas DPPH dari ekstrak daun kelor dan vitamin C. Nilai probit ditentukan menggunakan rumus:

Probit $=($ Harga probit tertinggi - Harga probit terendah) (Daya Antioksidan (\%) probit terendah) + Harga Probit terendah

Selanjutnya menghubungkan nilai probit dan nilai log konsentrasi yang diperoleh dalam 1 grafik utuh, dimana nilai $\log$ konsentrasi dijadikan sebagai sumbu $\mathrm{X}$ dan nilai probit digunakan sebagai sumbu $\mathrm{Y}$ seperti tampak pada Gambar 4.Berdasarkan Gambar tersebut diperoleh persamaan regresi linear $Y=1,8731 \mathrm{X}$ $+2,4804$ untuk esktrak etanol, $Y=1,4619 X$ $+2,4265$ untuk ekstrak air, dan $Y=1,2294 X$ $+3,8383$ untuk vitamin C (Pembanding/ Kontrol positif). Melalui persamaan regresi yang diperoleh pada Gambar 4, nilai Xdapat ditentukan setelah mengganti nilai $Y=5$ yang merupakan harga probit dari 50\%. Selanjutnya nilai $\mathrm{IC}_{50}$ ditentukan dengan menggunakan rumus $\mathrm{IC}_{50}=\mathrm{A} \log \mathrm{X}$.

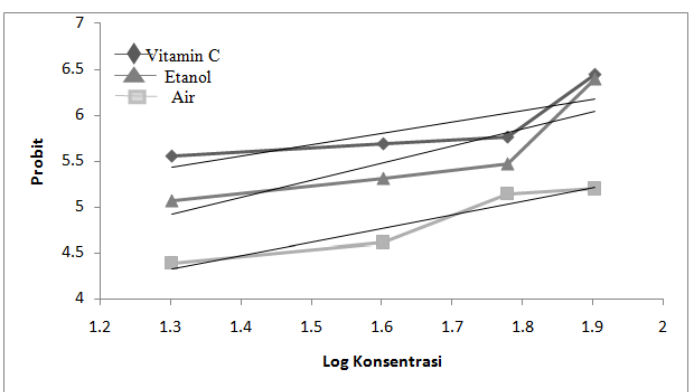

Gambar 5 Hubungan Log konsentrasi dan Probit Antara Vitamin C, Ekstrak Etanol dan Ekstrak Air Dari Daun Kelor.

Berdasarkan Gambar 4 diperoleh nilai $r$ untuk ekstrak etanol, air dan Vitamin C sebagai kontrol positif yaitu masing-masing 0,7082; 0,9156; dan 0,6488. Nilai $\mathrm{r}$ yang diperoleh dapat diartikan bahwa data probit dari ekstrak 
daun kelor dengan pelarut air yang diperoleh lebih baik dari pada data probit daun kelor dengan pelarut etanol dan data probit vitamin C. Jika grafik hasil perhitungan memiliki nilai $r$ mendekati 1 atau sama dengan 1 , maka data hasil penelitian yang diperoleh sangat baik. Oleh karenanya nilai $r$ yang diperoleh untuk ekstrak daun kelor dengan menggunakan pelarut air dan vitamin $\mathrm{C}$ dapat dikatakan kurangbaik. Hal ini kemungkinan disebabkan karena 3 hal, yaitu: (1) kurang baiknya pembuatan deret konsentrasi larutan yang digunakan (2) instrument (spektrophotometer UV-Vis) yang tidak dikalibrasi secara benar, dan (3) pengotor dalam tabung reaksi yang digunakan sebagai tempat awal larutan (Day, 1999).Nilai $\mathrm{IC}_{50}$ yang diperoleh dari hasil perhitungan akhir yaitu untuk ekstrak air dari daun kelor mempunyai $\mathrm{IC}_{50}$ sebesar $57,5439 \mathrm{ppm}$, untuk ekstrak etanol dari daun kelor mempunyai $\mathrm{IC}_{50}$ sebesar 22,1818 ppm, sedangkan IC50 yang dihasilkan vitamin $\mathrm{C}$ sebesar 8,8084 ppm. Hal ini menjelaskan bahwa kemampuan menangkap radikal bebas daun kelor dengan menggunakan ekstrak air termasuk dalam golongan kuat, sedangkan daun kelor dengan menggunakan ekstrak etanol termasuk dalam golongan sangat kuat dikarenakan nilai $\mathrm{IC}_{50}$ yang diperolehdari perhitungan kurang dari $50 \mathrm{ppm}$ untuk ekstrak etanol sedangkan untuk ekstrak air di atas $50 \mathrm{ppm}$. Hal ini sesuai dengan literatur yang mengatakan bahwa tingkat kekuatan antioksidan menggunakan metode $\mathrm{DPPH}$ dapat digolongkan menurut $\mathrm{IC}_{50}$. Antioksidan sangat kuat jika nilai IC50kurang dari 50 ppm, kuat jika $\mathrm{IC}_{50}$ bernilai $50-100$ ppm, sedang jika $\mathrm{IC}_{50}$ bernilai $100-150 \mathrm{ppm}$, dan lemah jika $\mathrm{IC}_{50}$ bernilai lebih dari 150 ppm(Molyneux, 2004). Semakin kecil nilai IC50berarti semakin kuat daya antioksidannya. Vitamin C sebagai pembanding atau kontrol positif termasuk antioksidan yang lebih kuat jika dibandingkan dengan ekstrak daun kelor yang digunakan sebagai sampel pada penelitian ini, hal ini bisa dilihat dari nilai $\mathrm{IC}_{50}$ untuk vitamin $C$ yang diperoleh yaitu 8,8084 ppm.

\section{Kesimpulan}

Ekstrak etanol daun kelor dengan menggunakan metode maserasi memiliki daya antioksidan dengan nilai $\mathrm{IC}_{50}$ sebesar 22,1818 ppm, sedangkan ekstrak air daun kelor dengan menggunakan metode dekok memiliki $\mathrm{IC}_{50}$ sebesar 57,5439 ppm. Berdasarkan data $\mathrm{IC}_{50}$ tersebutdapat diketahui bahwa antioksidan
Vitamin C lebih kuat dari ekstrak daun kelor, dimana nilai $\mathrm{IC}_{50}$ dari Vitamin $\mathrm{C}$ yaitu 8,8084 ppm.

\section{Ucapan Terima Kasih}

Ucapan terima kasih penulis berikan kepada laboran Laboratorium Kimia Fakultas Keguruan dan Ilmu Pendidikan Universitas Tadulako yang banyak membantu penulis dalam menyelesaikan penelitian ini.

\section{Referensi}

Aliya. (2006). Mengenal teknik penjernihan air. Semarang: CV Aneka Ilmu.

Day, R. A. (1999). Analisis kimia kuantitatif. Edisi keenam. Jakarta: Erlangga.

Gordon, M. H. (1990). The mechanism of antioxidants action in vitro. In $b . J$. F Hudson,.Editor.Food antioxidants. London: Elvesier Applied Science.

Halliwel, B. (2007). Dietary polyphenols: Good, bad, or indifferent for your health. Journal Cardiovascular Research, 73, 341347.

Karyadi. (2004). Antioksidan resep sehat dan umur panjang: http://www.kompas.com/ kesehatan/news/0601/29/185345.htm. Diakses 10 Juni 2015.

Molyneux, P. (2004). The use of the stable free radical diphenylpicrylhydrazyl (dpph) for estimating antioxidant activity. Songklanakarin Journal Science Technology, 26(2), 211-219.

Ozcelik, B., Lee, J. H., \& Min, D. B. (2003). Effect of light, oxygen, and $\mathrm{pH}$ on the absorbance of 2,2-diphenyl-1picrylhidrazyl. Journal Food Science, 68, 487-490.

Palupi, N., Zakaria, F., \& Prangdimurti, E. (2007). Pengaruh pengelolahan terhadap nilai gizi pangan. Departemen Ilmu Dan Teknologi Pangan-Fateta-IPB: Modul e-Learning.

Pietta. P. G. (2000). Flavonoids as antioxidants. Journal of Natural Product, 63(7), 10351042.

Prakash, A. (2011). Antioxidant activity. Medallion laboratories. Journal Analytical Progress, 19(2), 1-6. 
Roloff, A., Weisgerber, H., Lang, U., \& Silalahi, J. (2006). Makanan fungsional. Stimm, B. (2009). Moringa oleifera LAM. 1785. Http://Contet.schweitzer-online. de: WILET-VCH Verlang GmbH \& Co. KGaA, weinheim.

Sarastani, D., Suwarna, T., \& Apriyanto, A. (2002). Aktivitas antioksidan ekstrak dan fraksi ekstrak biji atung. Jurnal Teknologi dan Industri Pangan, 13(2), 149-156.

Yogjakarta: Kanisius.

Talapessy, S., Suryanto, E., \& Yudistira, A. (2013). Uji aktivitas antioksidan dari ampas hasil pengolahan sagu (metroxylon sagu rottb). Jurnal Ilmiah Farmasi, 2(3), 40-44.

Winarsi, H. M. S. (2007). Antioksidan alami dan radikal bebas. Yogyakarta: Kansius.

Shintia, S. T., Jemmy, A., \& Frenly, W. (2014). Aktivitas Antioksidan Dan Kandungan Total Fenolik Ekstrak Daun Kelor (Moringa Oleifera Lam). Jurnal Ilmiah Farmasih UNSART, 3(4), 2302-2493.

Zuhra, C. F., Tarigan, J. B., \& Sihotang, H. (2008). Aktivitas antioksidan senyawa flavonoid dari daun katuk (sauropus androgunus(l) merr.). Jurnal Biologi Sumatera, 3(1), 7-10. 